
Wicked Philosophy 


\section{Wicked Philosophy}

\section{Philosophy of Science and Vision Development for Complex Problems}

Coyan Tromp

Amsterdam University Press 


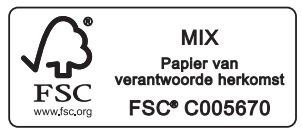

Volume 5 of the Series Perspectives on Interdisciplinarity

Cover design and lay-out: Matterhorn Amsterdam

$\begin{array}{ll}\text { ISBN } & 9789462988774 \\ \text { e-ISBN } & 978904854 \text { I09 } 6 \text { (pdf) } \\ \text { DOI } & \text { I0.5II7/9789462988774 } \\ \text { NUR } & 734\end{array}$

(C) Coyan Tromp / Amsterdam University Press B.V., Amsterdam 2018

All rights reserved. Without limiting the rights under copyright reserved above, no part of this book may be reproduced, stored in or introduced into a retrieval system, or transmitted, in any form or by any means (electronic, mechanical, photocopying, recording or otherwise) without the written permission of both the copyright owner and the author of the book.

Every effort has been made to obtain permission to use all copyrighted illustrations reproduced in this book. Nonetheless, whosoever believes to have rights to this material is advised to contact the publisher. 
For Future Planet Frontrunners

Jim, Sjoerd, Sjef, Jasper, Vera and Marinus who inspire me to inspire others 